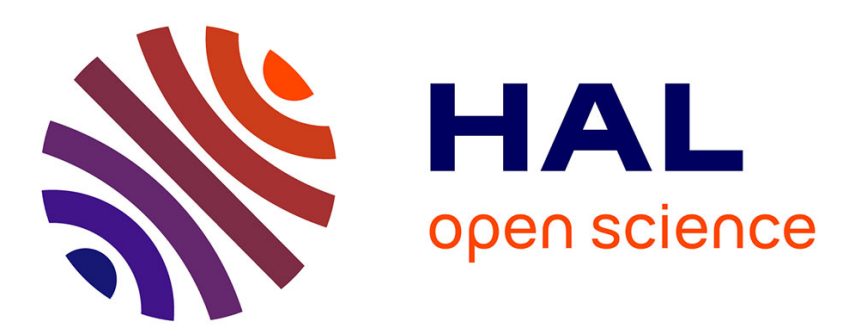

\title{
T-type calcium channels in neuropathic pain
}

Emmanuel Bourinet, Amaury François, Sophie Laffray

\section{To cite this version:}

Emmanuel Bourinet, Amaury François, Sophie Laffray. T-type calcium channels in neuropathic pain. Pain, 2016, 157 Suppl 1, pp.S15-22. 10.1097/j.pain.0000000000000469 . hal-02356330

\section{HAL Id: hal-02356330 \\ https://hal.science/hal-02356330}

Submitted on 15 Dec 2020

HAL is a multi-disciplinary open access archive for the deposit and dissemination of scientific research documents, whether they are published or not. The documents may come from teaching and research institutions in France or abroad, or from public or private research centers.
L'archive ouverte pluridisciplinaire HAL, est destinée au dépôt et à la diffusion de documents scientifiques de niveau recherche, publiés ou non, émanant des établissements d'enseignement et de recherche français ou étrangers, des laboratoires publics ou privés. 


\section{T-type calcium channels in neuropathic pain}

Emmanuel Bourinet ${ }^{\mathrm{a}, \mathrm{b}, \mathrm{c}, \mathrm{d}}$ Amaury Francois ${ }^{\mathrm{e}}$, Sophie Laffray ${ }^{\mathrm{a}, \mathrm{b}, \mathrm{c}, \mathrm{d}}$,

(a) Laboratories of Excellence, Ion Channel Science and Therapeutics, Institut de Génomique Fonctionnelle, 141 rue de la Cardonille, F-34094 Montpellier, France, (b) CNRS UMR5203, Montpellier, France, (c) INSERM, U661, Montpellier, France, (d) Université de Montpellier, Montpellier, France, (e) Dept. of Anesthesiology, Perioperative and Pain Medicine, Stanford Neurosciences Institute, 1050 Arastradero Road, Palo Alto CA 94304-5589, USA.

\section{Correspondence:}

Dr Bourinet, IGF, CNRS UMR5203, 141 rue de la Cardonille, 34094 Montpellier, France email : emmanuel.bourinet@igf.cnrs.frTel 33(0)4 34359248 Fax 33 (0)4 67542432 
Pain is a quite frequent complaint accompanying numerous pathologies. Among these pathological cases numerous neuropathies are retrieved with identified etiologies (chemotherapies, diabetes, surgeries...) and also more diffuse syndromes such as fibromyalgia. More broadly, pain is one of the first consequences of the majority of inherited diseases. Despite its importance for the quality of life, current pain management is limited to drugs that are either old, or with a limited efficacy or that possess a bad benefit/risk ratio. As no new pharmacological concept has led to new analgesics in the last decades, the discovery of new medications is needed, and to this aim the identification of new druggable targets in pain transmission is a first step. Therefore studies of ion channels in pain pathways are extremely active. This is particularly true with ion channels in peripheral sensory neurons in Dorsal Root Ganglia (DRG) known now to express unique sets of these channels. Moreover, both spinal and supra spinal levels are clearly important in pain modulation. Among these ion channels, we and others revealed the important role of low voltage-gated calcium channels in cellular excitability in different steps of the pain pathways. These channels, by being activated nearby resting membrane potential have biophysical characteristics suited to facilitate action potential generation and rhythmicity. In this review we will review the current knowledge on the role of these channels in the perception and modulation of pain.

\section{Calcium channel subtypes and molecular composition}

While a number of ionic conductances contribute to neuronal firing, voltage-gated calcium channels are unique in being involved in both shaping the action potential and triggering downstream an array of physiological cytoplasmic processes. Calcium entry via voltage gated calcium channels triggers cytoplasmic processes including the activation of calcium dependent enzymes, gene transcription, and the release of neurotransmitter from presynaptic nerve terminals. Most neurons express multiple types of calcium channels which 
have been classified into high and low voltage activated channels based on their voltagedependences of activation [89]. High voltage-activated calcium channels include pharmacologically distinct N-, P/-, Q-, R- and L-types, all of which are heteromultimers that consist of a pore forming $\alpha 1$ subunit which defines the channel type, plus one of four different types of $\beta$ subunits and one of four different $\alpha 2-\delta$ subunits as largely described in the present book. The low voltage-activated channels (also known as T-types) appear to consist only of the $\alpha 1$ subunit since its sole expression in recombinant systems recapitulates the properties of native channels. Moreover, no evidence of essential auxiliary subunits has been provided to date. The present picture arising from the completion of sequencing of multiple mammalian genomes shows that ten different types of calcium channel $\alpha 1$ subunits are distributed into 3 families (Cav1, Cav2, and Cav3) based on their homology of sequence. They correspond to the native calcium channel functionally identified in excitable cells by electrophysiological means. These subunits share a similar transmembrane topology, being comprised of four homologous domains, each containing six putative transmembrane helices (S1 through S6) plus a re-entrant pore forming loop. The four domains are connected via large cytoplasmic linker regions which are molecular platforms for protein kinases, and form interaction sites for multiple regulatory proteins, such as $\mathrm{G}$ protein $\beta \gamma$ subunits or the calcium channel $\beta$ subunits in the case of Cav1 and Cav2 $\alpha 1$ subunits.

Different calcium channel isoforms show distinct cellular and subcellular distributions, and fulfill specific functional roles. The Cav1 family is more involved in excitation contraction coupling, while the Cav2 family members by being expressed at presynaptic terminals are more involved in the control of neurotransmitter release from nerve terminals. These two a1 families may also partake in the activation of calcium dependent enzymes and gene transcription [141]. However, the exact roles and distributions of each channel subtypes are neuron subtype dependent, such that most types of calcium channels are expressed at various subcellular loci 
and do in fact support a wider range of functions. These diverse functional roles ultimately pose a challenge when designing new calcium channel therapeutics with a low risk of side effects. At the molecular and biochemical level, T-type calcium channels are formed by a single Cava1 subunit - a $\sim 250 \mathrm{KDa}$ protein that is comprised, as for the HVA calcium channel subunits of four membrane domains that are connected by cytoplasmic regions and whose Nand C-termini are also cytoplasmic [16]. Each membrane domain contains six membrane spanning helices (S1 though S6) that include a voltage sensor region plus a re-entrant p-loop motif that lines the pore of the channel and controls ion selectivity. The mammalian genome encodes three distinct T-type calcium channel $\alpha 1$ subunits, termed Cav3.1, Cav3.2 and Cav3.3 [24; 68; 99; 100] and which show distinct brain tissue distributions [80; 121]. In addition to the multiplicity of genes, all of the known Caval subunits undergo alternate splicing, in some cases giving rise to channels with dramatically different functional behavior $[1 ; 12 ; 72 ; 114$; 122; 123]. Each of the Cav3.x subunits are subject to alternate splicing $[17 ; 26 ; 84 ; 102 ; 110]$ with alteration of functional properties. The consequence of splicing for Cav3.x subcellular or tissue distribution is largely unknown so far.

Primary afferent neurons as well as spinal and supraspinal neurons of the pain circuitry express multiple types of voltage gated calcium channels, including the three Cav3 isoforms coding for T-type channels. Below, we will highlight the roles of Cav3.1, Cav3.2 and Cav3.3 in pain transmission, and their usefulness as targets for analgesics.

\section{T-type calcium channels and pain signaling}

By virtue of their hyperpolarized voltage-activation range and window current, T-type (Cav3) calcium channels are ideally suited to regulate neuronal excitability, as evident from their role in the development of spike and wave discharges in the epileptic brain (for review, see $[59 ; 145])$. They share this peculiarity with a number of other "threshold" ion channels all 
important for initiating and boosting cell excitability. These includes HCN channels, some potassium channel isoforms such as KCNQs, or the famous Nav1.7 sodium channel largely studied in the context of pain pathophysiology owing its gain or loss of function in congenital pain diseases that respectively increase or dampen nociception. In this electrogenic effect of Ttype channels compared to the different other threshold channels, one could note that their range of activation is even lower than Nav1.7 for example suggesting a role of preamplifier that favors sodium spike generation. In addition to their direct electrogenic role of calcium influx mediated regulation of a numbers of other conductances such as potassium channels[77; 129], T-type calcium channels also support secretion from neuroendocrine cells [40; 91] and are capable of associating with the synaptic vesicle release machinery [138]. T-type channels have been firstly well described functionally in primary sensory neurons [9; 15; 35; 37]. Following this initial discovery, DRG neurons subtypes have been show to deferentially express T-type calcium channels with medium sized neurons being the cells with the highest expressers followed with small putative nociceptors [109]. In addition kinetics differences suggested the presence of two distinct T-type channels in these neurons [23; 101]. With the molecular identification of the Cav3.x gene family and the subsequent in situ hybridization analysis, it was clearly shown that Cav3.2 is highly expressed in small and medium sized DRGs as well as Cav3.3 to a lower extent in small neurons [115; 121] (Allen Brain Atlas: www.brain-map.org). The popularisation of large scale transcriptomic profiling combined to individual cell analysis or cell sorting of genetically marked DRG classes recently confirmed that Cav3.2 and Cav3.3 are selectively expressed in defined subclasses of primary sensory neurons [103; 131]. Along these lines, Ttype calcium channels have been implicated in synaptic release in the dorsal horn of the spinal cord [51; 126]. Cav3.2 calcium channels are expressed in various subpopulations of primary afferent neurons $[11 ; 125]$ altogether suggesting a role of these channels in pain processing. Consistent with this idea, systemic or intrathecal delivery of T-type calcium channel blockers 
such as ethosuximide and mibefradil mediates analgesia in rodents [27; 36]. On the flip side, T-type calcium channel activity is increased in afferent pain fibers in a number of chronic pain conditions, such as after different types of traumatic nerve injury [52; 140; 144], metabolic nerve alteration in diabetic neuropathy [14; 53], or toxic neuropathies induced by chemotherapies [36; 57; 92]. At least in the case of diabetic neuropathy, blocking T-type channel activity restores a normal pain phenotype [65; 81; 90]. Of particular note, Cav3.2 activity is modulated by glycosylation that is altered in diabetic situation [94; 137] offering a molecular substrate to pharmacologically control Cav3.2 cell surface expression in a therapeutic perspective. Reinforcing the notion of pronociceptive effect of Cav3.2, the T-type channel agonist ST-101 efficient on Cav3.2 was shown to increase DRG cell excitability [29], although the selectivity of this remains to be fully demonstrated. Redox modulation is another means that effectively affect Cav3.2 function and that could be a major component of inflammatory or neuropathic pain via the action of L cysteine or the gasotransmiter hydrogen sulfide [74; 127], although pronociceptive effect of H2S are debated [32]. As a consequence, anti-oxidants could be analgesic by targeting Cav3.2 [69; 87; 88]. Mechanically, pathological increase of Cav3.2 currents in neurons has been show to results from multiple mechanisms from initial increased transcription [132] involving Egr1 a transcription factor activated by electrical activity particularly in the context pain [75], to increased channel trafficking to the membrane [76]. Recently, the molecular basis of this increased Cav3.2 presence at DRG cell membrane in pain syndromes was identified as the result of a deubiquitination mechanism selectively orchestrated by the USP5 deubiquitinase enzyme forming a molecular complex with the channel [42]. These findings offers an opportunity to discover novel analgesics designed to shorten Cav3.2 channel residence time at the cell membrane by disrupting their interaction with USP5. Dr Zamponi and coworkers validated this elegant approach in both inflammatory and neuropathic pain models [41]. 
In vivo, we and others evidenced that direct silencing of Cav3.2 calcium channels (but not other T-type calcium channel isoforms) in DRGs via antisense oligonucleotides or siRNA reduces mechanical nociception, and tactile allodynia arising from traumatic or metabolic nerve injury $[11 ; 81 ; 120]$. This fits globally with observations showing that Cav3.2 channels regulate mechanosensitivity of A $\delta$-LTMR fibers $[31 ; 136]$, but the notion that the main impact on somatosensation of Cav3.2 is due to their presence in A $\delta$-LTMRs is certainly excessive. Moreover this class of fiber, although present in rodents, has not been identified functionally in humans in contrary to other LTMR subtypes (A $\beta$ and $\mathrm{C}$ ) [67; 79]. To address this issue, we engineered a unique knockin/flox mouse strain where Cav3.2 is replaced by a functional Cav3.2-surface-eclipticGFP fusion that also has a floxed exon[39]. Using this approach we first demonstrated that Cav3.2 is indeed a selective marker of two major low-threshold mechanoreceptors, A $\delta$ - and C-LTMRs, innervating the most abundant hair follicles in the skin. Moreover by generating of a C-LTMR specific Cav3.2 conditional knock out we uncovered that Cav3.2 withing these C-LTMRs regulates light-touch perception, noxious mechanical cold and chemical sensations, and is essential to build-up debilitating allodynic symptoms of neuropathic pain, a mechanism thought and reported in the literature to be entirely A-LTMRsspecific. Collectively these findings globally help to further understand the fundamental role for Cav3.2 in touch/pain pathophysiology, validating their critic pharmacological relevance to relieve mechanical and cold allodynia. These data confirm recent description of a number of CLTMR specific genes by deep RNA Seq sequencing following DRG subtype FACS sorting or individual single cell DRG isolation showing that Cav3.2 is indeed a marker of these neurons [103; 131]. These findings on somatic nociception can be extended to painful situations linked to visceral origin. In a rodent model of colonic hypersensitivity mimicking the Irritable Bowel Syndrome [10], in vivo knockdown of Cav3.2 channels reverses pain hypersensitivity in response to colorectal distension [76]. These findings are further supported by analysis of other 
visceral chronic pain models [74; 78; 83; 124]. Altogether, these data indicate that T-type channel membrane expression is dynamically regulated and increased under conditions of chronic pain, and that counteracting this aberrant upregulation may constitute an effective means of mediating analgesia. It is interesting to note that mice lacking Cav3.2 in the constitutive knock out [18] show hyposensitivity to basal nociception, to formalin induced pain in both phases, and a more limited effect on neuropathic pain [21] suggesting possible compensatory phenomenon. The availability of floxed Cav3.2 model opens interesting perspective on inducible localized KO that will limit these compensations.

Compared to the DRGs, at the spinal level little is known on the impact of T-type channels but nickel sensitive low voltage gated evoked and spontaneous neurotransmitter release has been described between primary afferent neurons and outer laminas spinal projection or interneurons [2]. Recent evidences using the Cav3.2 KO mice confirmed these results [42; 51]. Moreover the implication of Cav3.2 in the presynaptic neurotransmitter release machinery is an emerging concept [48; 138; 139]. In this context, our morphological data with the Cav3.2-GFP mouse argue for a specific expression of Cav3.2 in inner lamina II receiving low threshold mechanoreceptive fibers namely the C-LTMRs and the A- $\delta$ LTMRs[39]. Moreover, electron microscopy analysis of the glomeruli structure of the synapses at this level reveals the presence of Cav3.2 at both sides of the synapses [39]. Postsynaptically, spinal projection and/or interneurons express functional T-type channels [49; 64; 134] with a selective expression in a subclass of lamina II interneurons whose function remains to be established [134]. Considering that the vast majority of spinal neurons are interneurons, the wiring underlying the spinal networks relaying sensory signaling is clearly not fully understood. In this context, a lot of explorations remain to be performed. Are T-type channels expressed in excitatory or inhibitory inter-neurons, in projection neurons? Specific genetic inactivation 
within the spinal cord sparing the primary afferent neurons is still waiting for behavioral analysis.

Anatomically, several ascending spinal pathways are heading towards the brain. These pathways serve not only thalamic targets but also a number of key brainstem nuclei, such as the parabrachial nucleus and periaqueductal grey, each of which also project higher in the brain. Moreover, pain-related functional changes across brain regions consistently reported activation of the thalamus, somatosensory cortex, Anterior Cingulate Cortex (ACC), prefrontal cortex (PFC), insula, amygdala, forming a so-called pain matrix. The excitability of the thalamocortical loop is based on the reciprocal connections between thalamus and cortex, TC neurons project to the cortex and receive a dense cortical excitatory feedback. Within this loop, a peculiar nucleus, the Nucleus Reticularis Thalami (NRT), exclusively composed of GABAergic neurons expressing a high density of Cav3.2 channels is considered as the "clock" of the system[25] due to its anatomical localization. Indeed NRT neurons receive excitatory inputs from both thalamocortical collaterals and cortical afferences, and provide inhibitory input to the TC neurons. Thalamic ventral posterior nucleus receives spino thalamic afferent tracts and projects to the primary somatosensory cortex implicated in sensory discrimination of noxious stimuli. Additional thalamic nuclei[56] project to other cerebral areas governing the emotional aspects of pain, including the insula and the AAC[56]. Of note the insular cortex has been shown to be the essential integrator of the inputs coming from the Cav3.2 expressing CLTMR fibers[39; 93]. In addition, nociceptive information reaches the thalamus through parallel pathways via the lateral hypothalamus or the amygdala [13; 112], two areas also implicated in the emotional aspects of pain. 
Mechanistically, neuroplasticity secondary to neuropathies decreases neuronal firing threshold, increases spontaneous firing and enhances firing evoked by repetitive stimulation[105; 142]. However to what extent T-type calcium channels are involved in these changes of excitability is unknown, despite their abundance in nearly all the regions of the pain network [121]. In the thalamus it is well known that both TC and NRT neurons display two modes of firing, the tonic and burst modes[105]. Indeed, the most remarkable feature characterizing the transition of the thalamocortical activity from wakefulness to sleep is the change in the firing patterns of thalamic neurons that is tightly linked to the biophysical properties of the T-type calcium channels. During sleep the prolonged hyperpolarization of the thalamic neurons massively de-inactivate the T-type channels and promote low threshold calcium spikes (LTS) generation and the occurrence of rhythmic high frequency bursting activities[119]. The cortical consequences of this T-type channel dependent bursting mode is reflected on the electroencephalogram (EEG) which is dominated during sleep by high amplitude, low frequency oscillatory activities $(<15 \mathrm{~Hz})$ and, by contrast, by low amplitude, high frequency oscillatory activities in the gamma band (30-50 Hz) during waking states. However, it is of great importance to note that clinical studies reported the presence of abnormal slow TC oscillations in the theta frequency band (4-8Hz) in awake neuropathic patients[55; 73; 135]. Moreover, thalamic bursting can lead to synaptic potentiation in the ACC, with important consequences regarding cortical integration of the nociceptive input and memory formation related to painful events and comorbidities such as anxiety[63; 117]. While plasticity of these synapse seems to rely on multiple mechanisms, it is worth to mention a recent brief report indicating the potential role of T-type channels in these neurons with an increased expression of Cav3.2 linked to neuropathic state[113]. As additional layer of regulation, interconnectivity within the cortical areas amplify chronic pain as described for the connection from the somatosensory S1 to the AAC[34]. Inversely, inhibition of ACC neurons with targeted 
inhibitory opsins recently showed the analgesic potential of impeding the excitability of this region[46]. This is largely due to the fact that the enhanced cingulate cortical output information augmented in chronic pain influence multiple subcortical targets such as the periaqueductal grey (PAG) and mesolimbic nuclei further building up the multidimensional aspects of pain including the motivational processing of the hedonic value of pain and pain relief [86].

Alteration of thalamic bursting, underlain by T-type currents, is therefore mechanistically a key element of pain network malfunctions as reported in patients[70; 71; 82] in association to theta rhythmicity[55; 107]. Animal studies corroborates these findings with enhanced bursting associated to spontaneous slow rhythmic oscillations [43; 50], reduced coherence between electrocorticogram and thalamic local field potential, and increased theta oscillations power[66] in neuropathic models. Similarly, bursting in ACC cortex of neuropathic rats has been linked to overexpressed Cav3.2 and modulated by T-type channel blocker [113]. As a whole, these data point to a crucial role played by supra spinal T-type channels in both the transfer of nociceptive information and the development of abnormal brain activities.

A more direct way to estimate the involvement of $\mathrm{T}$ channels in pain response is the use of genetically modified mice for the different Cav3 isoforms. However, experiments performed so far have involved general KO mice for the Cav3.1 or Cav3.2 channels and mostly non-specific T channel pharmacology (Mibefradil, Ethosuximide). The Cav3.3 KO model has not been explored for pain behavior yet. Hyperalgesia was first reported in response to visceral stimulation in the Cav3.1 null mice [60] exhibiting a total absence of T-type currents in somatosensory TC neurons $[61 ; 128]$. In contrast the global Cav3.2 KO exhibits an analgesic phenotype regarding different models of pain [3; 19; 21; 53]. Moreover our recent work shows that the analgesic effects of per os administered newly developed T-type channel agonist (affecting all 3 Cav3 isoforms) are abolished in the null mice showing that the blockade of T- 
type channels overall mediates analgesia[38]. Direct proof of central pronociceptive role of Cav3.x channels will require either local pharmacological approaches using specific $\mathrm{T}$ channel antagonist $[20 ; 28 ; 38]$ or conditional Cav3.x KO mice. This conclusion stands equally to unravel the impact of Cav3.x in the other regions of the pain matrix in the ascending as well as in the descending pathways. Although little is known on the impact of Cav3.x channels in descending pain modulation, it should be noted that in the bulbospinal area, namely in inhibitory periaqueductal gray gabaergic neurons, the lack of Cav3.1 KO mice perturb morphine analgesia [95]. These findings could indicate that PAG located Cav3.1 may limit persistent pain, but the use of TTA-A2, a Cav3.x pan antagonist do not result in similar effects. Further work need to be done to clarify this issue. Of note in that respect, we reported recently that intra cerebro ventricular (ICV) injection of TTA-A2 result in an analgesic effect that depends on Cav3.2 expression [33]. Moreover this study demonstrates that blockade of supraspinal Cav3.2 is a key step of the mechanism underlying the analgesic effect of paracetamol, the most widely use remedy to treat mild pain [33]. Interestingly, this study shows that the end up inhibition of Cav3.2 subsequent to the action of AM404, the active paracetamol metabolite, is due to the activation of centrally expressed TRPV1 channels that in turn leads to an inhibition of Cav3.2. This regulation has been similarly proposed in rat primary afferent neurons [22].

For all the aspects presented the precise spatial and temporal resolution of Cav3.x expression in the pain neuronal pathways both at the cellular and subcellular levels are crucial. Up to recently the state of the art on this aspect was inexistent. However, recently two independent groups reported that T-type calcium channels are concentrated in the Axon Initial Segment (AIS), where they contribute to local subthreshold membrane depolarization and thereby influence action potential initiation. These data were based on conclusion from functional studies on isolated neurons using cell attached patch clamp recordings as well as calcium and sodium imaging. Furthermore, these studies shows that this localization is a 
dynamically regulated process enabling a fine tuning of intrinsic plasticity of neuronal excitability $[4 ; 5 ; 44]$. This tuning of T-type channel localization is moreover regulated by membrane receptors such as the dopamine receptors also expressed in regions enriched in Cav3.2 [6; 118; 121]. The plastic alterations of T-type channels distribution are likely involved during chronic pain states. For this aspect the Cav3.2-GFP knockin mouse will be of great utility. While plasticity of channel distribution in pathological pain remains to be addressed, this tool helped to uncover that physiologically Cav3.2 proteins are expressed in the receptive fields of LTMR fibers nearby the hair follicles in the putative triggering zone of action potential firing (thereby contributing to the extreme sensitivity of these fibers to low mechanical forces), as well as along the axons of these neurons with a specific presence at the nodes of Ranvier of A $\delta$-LTMRs and in clusters along the C-LTMR fibers where it speed up conduction velocity [39]. This latter effect was retrieved recently in hippocampal and cerebellar neurons that respectively express Cav3.2 and Cav3.1 [45; 77]. Thus, the impact of T-type channel on axonal excitability is at its beginning but this is likely to drive increasing attention.

\section{T-type channel pharmacology: toward a new class of analgesics?}

Most of the work done so far validate the Cav3.2 isoform as a target for mediating analgesia, especially by acting in the periphery. It may be possible to exploit state dependence of drug action as a means to further preferentially inhibit T-type calcium channels in highly active pain fibers. Indeed, new generation of blockers appeared in the recent years with different scaffolds [7; 62; 96; 104; 116; 130; 143; 146]. In particular TTA-P2 and TTA-A2, the latter which interact preferentially with inactivated T-type calcium channels, both mediate analgesia in rodent models of pain [20; 38]. Z123212, a mixed blocker of voltage dependent sodium channels and T-type calcium channels mediates analgesia by selectively targeting the slow inactivated state of these channels [47]. In this context it is interesting to note that the 
local anesthetic binding domain of voltage gated sodium channels is partially conserved in Ttype calcium channels [8]. Given that there is now a crystal structure of a bacterial voltage gated sodium channels [97; 98] this knowledge may help guide further development of T-type channel blocking drugs. Finally, Z944, another state dependent T-type channel inhibitor is currently in phase I clinical trials for pain. Several pharmaceutical companies have T-type channels on their list of targets and near future will show if clinical drugs emerge. The use of tissue specific Cav3.X conditional KO will be in the future a nice perspective to decipher the important structures mediating the analgesic effects of T-type channels blockers. Translationnal value of preclinical research in the field of pain is always debated regarding the number of molecules that failed in their clinical development. Going from mouse to men targeting T-type channel may be a successful story regarding recent published data. Dr David Mahns and coworkers recently used the TTA-A2 in humans with local injection in the skin. They demonstrated that T-type channel blockade efficiently attenuated mechanical and cold allodynia by affecting C-LTMR (alias C-tactile in human) a striking parallel to our finding on mice $[85 ; 106]$. Although this contrast with the conclusions of a clinical trial on diabetic neuropathic patients with the ABT-639 molecule, a lower affinity new selective T-type channel blocker[54] that showed a disappointing lack of efficacy, although higher dose might have been needed to fully judge the drug efficacy [111; 147].

\section{Concluding remarks}

A number of questions concerning the role of T-type channels in pain remain unresolved. First, it is unclear precisely how T-type channels contribute to pain signaling. Possibilities include: 1) a lowering of the firing threshold for afferent pain fibers, 2) a direct contribution to neurotransmitter release at primary afferent synapses 3) a direct function of T- 
type channels as mechanosensors, 4) an activation of pathways such as ERK which in turn is linked to increased pain [19] and 5) perhaps via interactions with other types of ion channels such as voltage- and calcium-activated potassium channels as described for different types of CNS neurons. Second, the mechanism by which T-type calcium channel activity is enhanced in chronic pain conditions remains to be determined such as direct modulations, posttranslational modifications, and altered membrane turnover. This could potentially include the Cav $\alpha 2 \delta$ subunit which has been shown to increase T-type channel amplitude in expression systems [30]. Finally, a number of inherited mutations have been described for the Cav3.2 coding gene in rats [102] and more importantly in humans [58; 108; 118; 133]. Although they are linked to some forms of epilepsies, autism or metabolic disorders, it remains to be explored if these patients suffer from altered pain perception.

In summary, among the calcium channel family the T-type calcium channels and in particular the Cav3.2 isoform appear to have a critical role in the excitability of pain neuronal circuits, and as a result are vigorously pursued as therapeutic targets.

\section{Acknowledgments}

We thank all members of Bourinet's lab, and our collaborators (Drs A Eschalier, A Moqrich, O Pongs, GW Zamponi) for their direct contribution to the work on the study of Ttype calcium channel in the pathophysiology of pain. Pain related work conducted in the authors' laboratory is supported by the Agence Nationale pour la Recherche, Association Française pour les Myopathies, Institut UPSA de la Douleur, and the Fondation pour la Recherche Médicale. Authors declare no conflicts of interests. 


\section{References:}

[1] Allen SE, Darnell RB, Lipscombe D. The neuronal splicing factor Nova controls alternative splicing in N-type and P-type CaV2 calcium channels. Channels (Austin) 2010;4(6):483-489.

[2] Bao J, Li JJ, Perl ER. Differences in Ca2+ channels governing generation of miniature and evoked excitatory synaptic currents in spinal laminae I and II. J Neurosci 1998;18(21):8740-8750.

[3] Barbara G, Alloui A, Nargeot J, Lory P, Eschalier A, Bourinet E, Chemin J. T-type calcium channel inhibition underlies the analgesic effects of the endogenous lipoamino acids. J Neurosci 2009;29(42):13106-13114.

[4] Bender KJ, Ford CP, Trussell LO. Dopaminergic modulation of axon initial segment calcium channels regulates action potential initiation. Neuron 2010;68(3):500-511.

[5] Bender KJ, Trussell LO. Axon initial segment Ca2+ channels influence action potential generation and timing. Neuron 2009;61(2):259-271.

[6] Bergquist F, Nissbrandt H. Influence of R-type (Cav2.3) and t-type (Cav3.1-3.3) antagonists on nigral somatodendritic dopamine release measured by microdialysis. Neuroscience 2003;120(3):757-764.

[7] Bladen C, McDaniel SW, Gadotti VM, Petrov RR, Berger ND, Diaz P, Zamponi GW. Characterization of novel cannabinoid based T-type calcium channel blockers with analgesic effects. ACS chemical neuroscience 2015;6(2):277-287.

[8] Bladen C, Zamponi GW. Common mechanisms of drug interactions with sodium and T-type calcium channels. Mol Pharmacol 2012;82(3):481-487.

[9] Bossu JL, Feltz A, Thomann JM. Depolarization elicits two distinct calcium currents in vertebrate sensory neurones. Pflugers Arch 1985;403(4):360-368.

[10] Bourdu S, Dapoigny M, Chapuy E, Artigue F, Vasson MP, Dechelotte P, Bommelaer G, Eschalier A, Ardid D. Rectal instillation of butyrate provides a novel clinically relevant model of noninflammatory colonic hypersensitivity in rats. Gastroenterology 2005;128(7):1996-2008. 
[11] Bourinet E, Alloui A, Monteil A, Barrere C, Couette B, Poirot O, Pages A, McRory J, Snutch TP, Eschalier A, Nargeot J. Silencing of the Cav3.2 T-type calcium channel gene in sensory neurons demonstrates its major role in nociception. Embo J 2005;24(2):315-324.

[12] Bourinet E, Soong TW, Sutton K, Slaymaker S, Mathews E, Monteil A, Zamponi GW, Nargeot J, Snutch TP. Splicing of alpha 1A subunit gene generates phenotypic variants of P- and Q-type calcium channels. Nat Neurosci 1999;2(5):407-415.

[13] Braz JM, Nassar MA, Wood JN, Basbaum AI. Parallel "pain" pathways arise from subpopulations of primary afferent nociceptor. Neuron 2005;47(6):787-793.

[14] Cao XH, Byun HS, Chen SR, Pan HL. Diabetic neuropathy enhances voltage-activated Ca2+ channel activity and its control by M4 muscarinic receptors in primary sensory neurons. J Neurochem 2011;119(3):594-603.

[15] Carbone E, Lux HD. A low voltage-activated, fully inactivating Ca channel in vertebrate sensory neurones. Nature 1984;310(5977):501-502.

[16] Catterall WA. Voltage-gated calcium channels. Cold Spring Harbor perspectives in biology 2011;3(8):a003947.

[17] Chemin J, Monteil A, Bourinet E, Nargeot J, Lory P. Alternatively spliced alpha(1G) (Ca(V)3.1) intracellular loops promote specific $\mathrm{T}$-type $\mathrm{Ca}(2+)$ channel gating properties. Biophys $\mathrm{J}$ 2001;80(3):1238-1250.

[18] Chen CC, Lamping KG, Nuno DW, Barresi R, Prouty SJ, Lavoie JL, Cribbs LL, England SK, Sigmund CD, Weiss RM, Williamson RA, Hill JA, Campbell KP. Abnormal coronary function in mice deficient in alpha1H T-type Ca2+ channels. Science 2003;302(5649):1416-1418.

[19] Chen WK, Liu IY, Chang YT, Chen YC, Chen CC, Yen CT, Shin HS. Ca(v)3.2 T-type Ca2+ channel-dependent activation of ERK in paraventricular thalamus modulates acid-induced chronic muscle pain. J Neurosci 2010;30(31):10360-10368.

[20] Choe W, Messinger RB, Leach E, Eckle VS, Obradovic A, Salajegheh R, Jevtovic-Todorovic V, Todorovic SM. TTA-P2 is a Potent and Selective Blocker of T-type Calcium Channels in Rat Sensory Neurons and a Novel Antinociceptive Agent. Mol Pharmacol 2011. 
[21] Choi S, Na HS, Kim J, Lee J, Lee S, Kim D, Park J, Chen CC, Campbell KP, Shin HS. Attenuated pain responses in mice lacking $\mathrm{Ca}(\mathrm{V}) 3.2$ T-type channels. Genes Brain Behav 2007;6(5):425431.

[22] Comunanza V, Carbone E, Marcantoni A, Sher E, Ursu D. Calcium-dependent inhibition of T-type calcium channels by TRPV1 activation in rat sensory neurons. Pflugers Arch 2011;462(5):709722.

[23] Coste B, Crest M, Delmas P. Pharmacological dissection and distribution of NaN/Nav1.9, T-type Ca2+ currents, and mechanically activated cation currents in different populations of DRG neurons. J Gen Physiol 2007;129(1):57-77.

[24] Cribbs LL, Lee JH, Yang J, Satin J, Zhang Y, Daud A, Barclay J, Williamson MP, Fox M, Rees M, Perez-Reyes E. Cloning and characterization of alpha1H from human heart, a member of the T-type Ca2+ channel gene family. Circ Res 1998;83(1):103-109.

[25] Crick F. Function of the thalamic reticular complex: the searchlight hypothesis. Proc Natl Acad Sci U S A 1984;81(14):4586-4590.

[26] David LS, Garcia E, Cain SM, Thau E, Tyson JR, Snutch TP. Splice-variant changes of the $\mathrm{Ca}(\mathrm{V}) 3.2$ T-type calcium channel mediate voltage-dependent facilitation and associate with cardiac hypertrophy and development. Channels (Austin) 2010;4(5):375-389.

[27] Dogrul A, Gardell LR, Ossipov MH, Tulunay FC, Lai J, Porreca F. Reversal of experimental neuropathic pain by T-type calcium channel blockers. Pain 2003;105(1-2):159-168.

[28] Dreyfus FM, Tscherter A, Errington AC, Renger JJ, Shin HS, Uebele VN, Crunelli V, Lambert RC, Leresche N. Selective T-type calcium channel block in thalamic neurons reveals channel redundancy and physiological impact of I(T)window. J Neurosci 2009;30(1):99-109.

[29] Du X, Hao H, Gigout S, Huang D, Yang Y, Li L, Wang C, Sundt D, Jaffe DB, Zhang H, Gamper $\mathrm{N}$. Control of somatic membrane potential in nociceptive neurons and its implications for peripheral nociceptive transmission. Pain 2014;155(11):2306-2322.

[30] Dubel SJ, Altier C, Chaumont S, Lory P, Bourinet E, Nargeot J. Plasma Membrane Expression of T-type Calcium Channel \{alpha\}1 Subunits Is Modulated by High Voltage-activated Auxiliary Subunits. J Biol Chem 2004;279(28):29263-29269. 
[31] Dubreuil AS, Boukhaddaoui H, Desmadryl G, Martinez-Salgado C, Moshourab R, Lewin GR, Carroll P, Valmier J, Scamps F. Role of T-type calcium current in identified D-hair mechanoreceptor neurons studied in vitro. J Neurosci 2004;24(39):8480-8484.

[32] Elies J, Scragg JL, Huang S, Dallas ML, Huang D, MacDougall D, Boyle JP, Gamper N, Peers C. Hydrogen sulfide inhibits Cav3.2 T-type Ca2+ channels. FASEB J 2014;28(12):5376-5387.

[33] Eschalier A, Mallet C, Dubray C, Kerckhove N, Bourinet E. Use of ethosuximide for treating or preventing pain of inflammatory type, inflammation, migraine, cephalalgia, myalgia, tendinitis, dorsal pain, intestinal inflammatory disease and irritable bowel syndrome: CNRS CENT NAT RECH SCI (CNRS-C) UNIV AUVERGNE CLERMONT 1 (UYAU-Non-standard) UNIV CENT HOSPITALIER CLERMONT FERRAND (UYHO-Non-standard), 2015. p. 41.

[34] Eto K, Wake H, Watanabe M, Ishibashi H, Noda M, Yanagawa Y, Nabekura J. Inter-regional contribution of enhanced activity of the primary somatosensory cortex to the anterior cingulate cortex accelerates chronic pain behavior. J Neurosci 2011;31(21):7631-7636.

[35] Fedulova SA, Kostyuk PG, Veselovsky NS. Two types of calcium channels in the somatic membrane of new-born rat dorsal root ganglion neurones. J Physiol 1985;359:431-446.

[36] Flatters SJ, Bennett GJ. Ethosuximide reverses paclitaxel- and vincristine-induced painful peripheral neuropathy. Pain 2004;109(1-2):150-161.

[37] Fox AP, Nowycky MC, Tsien RW. Single-channel recordings of three types of calcium channels in chick sensory neurones. J Physiol 1987;394:173-200.

[38] Francois A, Kerckhove N, Meleine M, Alloui A, Barrere C, Gelot A, Uebele VN, Renger JJ, Eschalier A, Ardid D, Bourinet E. State-dependent properties of a new T-type calcium channel blocker enhance Ca(V)3.2 selectivity and support analgesic effects. Pain 2013;154(2):283-293.

[39] Francois A, Schuetter N, Laffray S, Sanguesa J, Pizzoccaro A, Dubel S, Mantilleri A, Nargeot J, Noel J, Wood JN, Moqrich A, Pongs O, Bourinet E. The Low-Threshold Calcium Channel Cav3.2 Determines Low-Threshold Mechanoreceptor Function. Cell Rep 2015;10(3):370-382.

[40] Gackiere F, Bidaux G, Delcourt P, Van Coppenolle F, Katsogiannou M, Dewailly E, Bavencoffe A, Van Chuoi-Mariot MT, Mauroy B, Prevarskaya N, Mariot P. CaV3.2 T-type calcium 
channels are involved in calcium-dependent secretion of neuroendocrine prostate cancer cells. J Biol Chem 2008;283(15):10162-10173.

[41] Gadotti VM, Caballero AG, Berger ND, Gladding CM, Chen L, Pfeifer TA, Zamponi GW. Small organic molecule disruptors of Cav3.2 - USP5 interactions reverse inflammatory and neuropathic pain. Mol Pain 2015;11:12.

[42] Garcia-Caballero A, Gadotti VM, Stemkowski P, Weiss N, Souza IA, Hodgkinson V, Bladen C, Chen L, Hamid J, Pizzoccaro A, Deage M, Francois A, Bourinet E, Zamponi GW. The Deubiquitinating Enzyme USP5 Modulates Neuropathic and Inflammatory Pain by Enhancing Cav3.2 Channel Activity. Neuron 2014;83(5):1144-1158.

[43] Gerke MB, Duggan AW, Xu L, Siddall PJ. Thalamic neuronal activity in rats with mechanical allodynia following contusive spinal cord injury. Neuroscience 2003;117(3):715-722.

[44] Grubb MS, Burrone J. Activity-dependent relocation of the axon initial segment fine-tunes neuronal excitability. Nature 2010;465(7301):1070-1074.

[45] Grundemann J, Clark BA. Calcium-Activated Potassium Channels at Nodes of Ranvier Secure Axonal Spike Propagation. Cell Rep 2015.

[46] Gu L, Uhelski ML, Anand S, Romero-Ortega M, Kim YT, Fuchs PN, Mohanty SK. Pain inhibition by optogenetic activation of specific anterior cingulate cortical neurons. PloS one 2015;10(2):e0117746.

[47] Hildebrand ME, Smith PL, Bladen C, Eduljee C, Xie JY, Chen L, Fee-Maki M, Doering CJ, Mezeyova J, Zhu Y, Belardetti F, Pajouhesh H, Parker D, Arneric SP, Parmar M, Porreca F, Tringham E, Zamponi GW, Snutch TP. A novel slow-inactivation-specific ion channel modulator attenuates neuropathic pain. Pain 2011;152(4):833-843.

[48] Huang Z, Lujan R, Kadurin I, Uebele VN, Renger JJ, Dolphin AC, Shah MM. Presynaptic HCN1 channels regulate Cav3.2 activity and neurotransmission at select cortical synapses. Nat Neurosci 2011;14(4):478-486.

[49] Ikeda H, Heinke B, Ruscheweyh R, Sandkuhler J. Synaptic plasticity in spinal lamina I projection neurons that mediate hyperalgesia. Science 2003;299(5610):1237-1240. 
[50] Iwata M, LeBlanc BW, Kadasi LM, Zerah ML, Cosgrove RG, Saab CY. High-frequency stimulation in the ventral posterolateral thalamus reverses electrophysiologic changes and hyperalgesia in a rat model of peripheral neuropathic pain. Pain 2011;152(11):2505-2513.

[51] Jacus MO, Uebele VN, Renger JJ, Todorovic SM. Presynaptic CaV3.2 Channels Regulate Excitatory Neurotransmission in Nociceptive Dorsal Horn Neurons. J Neurosci 2012;32(27):9374-9382.

[52] Jagodic MM, Pathirathna S, Joksovic PM, Lee W, Nelson MT, Naik AK, Su P, Jevtovic-Todorovic V, Todorovic SM. Upregulation of the T-type calcium current in small rat sensory neurons after chronic constrictive injury of the sciatic nerve. J Neurophysiol 2008;99(6):3151-3156.

[53] Jagodic MM, Pathirathna S, Nelson MT, Mancuso S, Joksovic PM, Rosenberg ER, Bayliss DA, Jevtovic-Todorovic V, Todorovic SM. Cell-specific alterations of T-type calcium current in painful diabetic neuropathy enhance excitability of sensory neurons. J Neurosci 2007;27(12):3305-3316.

[54] Jarvis MF, Scott VE, McGaraughty S, Chu KL, Xu J, Niforatos W, Milicic I, Joshi S, Zhang Q, Xia Z. A peripherally acting, selective T-type calcium channel blocker, ABT-639, effectively reduces nociceptive and neuropathic pain in rats. Biochem Pharmacol 2014;89(4):536-544.

[55] Jeanmonod D, Magnin M, Morel A. Low-threshold calcium spike bursts in the human thalamus. Common physiopathology for sensory, motor and limbic positive symptoms. Brain 1996;119 ( Pt 2):363-375.

[56] Jones EG. Viewpoint: the core and matrix of thalamic organization. Neuroscience 1998;85(2):331345.

[57] Kawabata A. [Targeting $\mathrm{Ca}(\mathrm{v}) 3.2$ T-type calcium channels as a therapeutic strategy for chemotherapy-induced neuropathic pain]. Nihon yakurigaku zasshi Folia pharmacologica Japonica 2013;141(2):81-84.

[58] Khosravani H, Altier C, Simms B, Hamming KS, Snutch TP, Mezeyova J, McRory JE, Zamponi GW. Gating Effects of Mutations in the Cav3.2 T-type Calcium Channel Associated with Childhood Absence Epilepsy. J Biol Chem 2004;279(11):9681-9684. 
[59] Khosravani H, Zamponi GW. Voltage-gated calcium channels and idiopathic generalized epilepsies. Physiol Rev 2006;86(3):941-966.

[60] Kim D, Park D, Choi S, Lee S, Sun M, Kim C, Shin HS. Thalamic control of visceral nociception mediated by T-type Ca2+ channels. Science 2003;302(5642):117-119.

[61] Kim D, Song I, Keum S, Lee T, Jeong MJ, Kim SS, McEnery MW, Shin HS. Lack of the burst firing of thalamocortical relay neurons and resistance to absence seizures in mice lacking alpha(1G) T-type Ca(2+) channels. Neuron 2001;31(1):35-45.

[62] Kim HS, Kim Y, Doddareddy MR, Seo SH, Rhim H, Tae J, Pae AN, Choo H, Cho YS. Design, synthesis, and biological evaluation of 1,3-dioxoisoindoline-5-carboxamide derivatives as Ttype calcium channel blockers. Bioorg Med Chem Lett 2007;17(2):476-481.

[63] Koga K, Descalzi G, Chen T, Ko HG, Lu J, Li S, Son J, Kim T, Kwak C, Huganir RL, Zhao MG, Kaang BK, Collingridge GL, Zhuo M. Coexistence of two forms of LTP in ACC provides a synaptic mechanism for the interactions between anxiety and chronic pain. Neuron 2015;85(2):377-389.

[64] Ku WH, Schneider SP. Multiple T-type Ca2+ current subtypes in electrophysiologically characterized hamster dorsal horn neurons: possible role in spinal sensory integration. J Neurophysiol 2011;106(5):2486-2498.

[65] Latham JR, Pathirathna S, Jagodic MM, Choe WJ, Levin ME, Nelson MT, Lee WY, Krishnan K, Covey DF, Todorovic SM, Jevtovic-Todorovic V. Selective T-type calcium channel blockade alleviates hyperalgesia in ob/ob mice. Diabetes 2009;58(11):2656-2665.

[66] Leblanc BW, Lii TR, Silverman AE, Alleyne RT, Saab CY. Cortical theta is increased while thalamocortical coherence is decreased in rat models of acute and chronic pain. Pain 2014;155(4):773-782.

[67] Lechner SG, Lewin GR. Hairy sensation. Physiology 2013;28(3):142-150.

[68] Lee JH, Daud AN, Cribbs LL, Lacerda AE, Pereverzev A, Klockner U, Schneider T, Perez-Reyes E. Cloning and expression of a novel member of the low voltage-activated T- type calcium channel family. J Neurosci 1999;19(6):1912-1921. 
[69] Lee WY, Orestes P, Latham J, Naik AK, Nelson MT, Vitko I, Perez-Reyes E, Jevtovic-Todorovic V, Todorovic SM. Molecular mechanisms of lipoic acid modulation of T-type calcium channels in pain pathway. J Neurosci 2009;29(30):9500-9509.

[70] Lenz FA, Gracely RH, Rowland LH, Dougherty PM. A population of cells in the human thalamic principal sensory nucleus respond to painful mechanical stimuli. Neurosci Lett 1994;180(1):4650.

[71] Lenz FA, Kwan HC, Dostrovsky JO, Tasker RR. Characteristics of the bursting pattern of action potentials that occurs in the thalamus of patients with central pain. Brain Res 1989;496(12):357-360.

[72] Lipscombe D, Andrade A, Allen SE. Alternative splicing: Functional diversity among voltagegated calcium channels and behavioral consequences. Biochim Biophys Acta 2012.

[73] Llinas RR, Ribary U, Jeanmonod D, Kronberg E, Mitra PP. Thalamocortical dysrhythmia: A neurological and neuropsychiatric syndrome characterized by magnetoencephalography. Proc Natl Acad Sci U S A 1999;96(26):15222-15227.

[74] Maeda Y, Aoki Y, Sekiguchi F, Matsunami M, Takahashi T, Nishikawa H, Kawabata A. Hyperalgesia induced by spinal and peripheral hydrogen sulfide: evidence for involvement of Cav3.2 T-type calcium channels. Pain 2009;142(1-2):127-132.

[75] Mamet J, Klukinov M, Yaksh TL, Malkmus SA, Williams S, Harris S, Manning DC, Taylor BK, Donahue RR, Porreca F, Xie JY, Oyarzo J, Brennan TJ, Subieta A, Schmidt WK, Yeomans DC. Single intrathecal administration of the transcription factor decoy AYX1 prevents acute and chronic pain after incisional, inflammatory, or neuropathic injury. Pain 2014;155(2):322-333.

[76] Marger F, Gelot A, Alloui A, Matricon J, Ferrer JF, Barrere C, Pizzoccaro A, Muller E, Nargeot J, Snutch TP, Eschalier A, Bourinet E, Ardid D. T-type calcium channels contribute to colonic hypersensitivity in a rat model of irritable bowel syndrome. Proc Natl Acad Sci U S A 2011;108(27):11268-11273.

[77] Martinello K, Huang Z, Lujan R, Tran B, Watanabe M, Cooper EC, Brown DA, Shah MM. Cholinergic afferent stimulation induces axonal function plasticity in adult hippocampal granule cells. Neuron 2015;85(2):346-363. 
[78] Matsunami M, Kirishi S, Okui T, Kawabata A. Chelating luminal zinc mimics hydrogen sulfideevoked colonic pain in mice: possible involvement of T-type calcium channels. Neuroscience 2011;181:257-264.

[79] McGlone F, Wessberg J, Olausson H. Discriminative and affective touch: sensing and feeling. Neuron 2014;82(4):737-755.

[80] McKay BE, McRory JE, Molineux ML, Hamid J, Snutch TP, Zamponi GW, Turner RW. Ca(V)3 T-type calcium channel isoforms differentially distribute to somatic and dendritic compartments in rat central neurons. Eur J Neurosci 2006;24(9):2581-2594.

[81] Messinger RB, Naik AK, Jagodic MM, Nelson MT, Lee WY, Choe WJ, Orestes P, Latham JR, Todorovic SM, Jevtovic-Todorovic V. In vivo silencing of the $\mathrm{Ca}(\mathrm{V}) 3.2$ T-type calcium channels in sensory neurons alleviates hyperalgesia in rats with streptozocin-induced diabetic neuropathy. Pain 2009;145(1-2):184-195.

[82] Modesti LM, Waszak M. Firing pattern of cells in human thalamus during dorsal column stimulation. Applied neurophysiology 1975;38(4):251-258.

[83] Murakami-Nakayama M, Tsubota M, Hiruma S, Sekiguchi F, Matsuyama K, Kimura T, Moriyama M, Kawabata A. Polaprezinc attenuates cyclophosphamide-induced cystitis and related bladder pain in mice. J Pharmacol Sci 2015;127(2):223-228.

[84] Murbartian J, Arias JM, Lee JH, Gomora JC, Perez-Reyes E. Alternative splicing of the rat Ca(v)3.3 T-type calcium channel gene produces variants with distinct functional properties(1). FEBS Lett 2002;528(1-3):272-278.

[85] Nagi SS, Dunn JS, Birznieks I, Vickery RM, Mahns DA. The effects of preferential A- and C-fibre blocks and T-type calcium channel antagonist on detection of low-force monofilaments in healthy human participants. BMC neuroscience 2015;16:52.

[86] Navratilova E, Porreca F. Reward and motivation in pain and pain relief. Nat Neurosci 2014;17(10):1304-1312.

[87] Nelson MT, Joksovic PM, Su P, Kang HW, Van Deusen A, Baumgart JP, David LS, Snutch TP, Barrett PQ, Lee JH, Zorumski CF, Perez-Reyes E, Todorovic SM. Molecular mechanisms of 
subtype-specific inhibition of neuronal T-type calcium channels by ascorbate. J Neurosci 2007;27(46):12577-12583.

[88] Nelson MT, Woo J, Kang HW, Vitko I, Barrett PQ, Perez-Reyes E, Lee JH, Shin HS, Todorovic SM. Reducing agents sensitize C-type nociceptors by relieving high-affinity zinc inhibition of T-type calcium channels. J Neurosci 2007;27(31):8250-8260.

[89] Nowycky MC, Fox AP, Tsien RW. Three types of neuronal calcium channel with different calcium agonist sensitivity. Nature 1985;316(6027):440-443.

[90] Obradovic A, Hwang SM, Scarpa J, Hong SJ, Todorovic SM, Jevtovic-Todorovic V. CaV3.2 Ttype calcium channels in peripheral sensory neurons are important for mibefradil-induced reversal of hyperalgesia and allodynia in rats with painful diabetic neuropathy. PloS one 2014;9(4):e91467.

[91] Okayama S, Imagawa K, Naya N, Iwama H, Somekawa S, Kawata H, Horii M, Nakajima T, Uemura S, Saito Y. Blocking T-type Ca2+ channels with efonidipine decreased plasma aldosterone concentration in healthy volunteers. Hypertension research : official journal of the Japanese Society of Hypertension 2006;29(7):493-497.

[92] Okubo K, Takahashi T, Sekiguchi F, Kanaoka D, Matsunami M, Ohkubo T, Yamazaki J, Fukushima N, Yoshida S, Kawabata A. Inhibition of T-type calcium channels and hydrogen sulfide-forming enzyme reverses paclitaxel-evoked neuropathic hyperalgesia in rats. Neuroscience 2011;188:148-156.

[93] Olausson H, Lamarre Y, Backlund H, Morin C, Wallin BG, Starck G, Ekholm S, Strigo I, Worsley K, Vallbo AB, Bushnell MC. Unmyelinated tactile afferents signal touch and project to insular cortex. Nat Neurosci 2002;5(9):900-904.

[94] Orestes P, Osuru HP, McIntire WE, Jacus MO, Salajegheh R, Jagodic MM, Choe W, Lee J, Lee SS, Rose KE, Poiro N, Digruccio MR, Krishnan K, Covey DF, Lee JH, Barrett PQ, JevtovicTodorovic V, Todorovic SM. Reversal of neuropathic pain in diabetes by targeting glycosylation of CaV3.2 T-type calcium channels. Diabetes 2013. 
[95] Park C, Kim JH, Yoon BE, Choi EJ, Lee CJ, Shin HS. T-type channels control the opioidergic descending analgesia at the low threshold-spiking GABAergic neurons in the periaqueductal gray. Proc Natl Acad Sci U S A 2010;107(33):14857-14862.

[96] Park JH, Choi JK, Lee E, Lee JK, Rhim H, Seo SH, Kim Y, Doddareddy MR, Pae AN, Kang J, Roh EJ. Lead discovery and optimization of T-type calcium channel blockers. Bioorg Med Chem 2007;15(3):1409-1419.

[97] Payandeh J, Gamal El-Din TM, Scheuer T, Zheng N, Catterall WA. Crystal structure of a voltagegated sodium channel in two potentially inactivated states. Nature 2012;486(7401):135-139.

[98] Payandeh J, Scheuer T, Zheng N, Catterall WA. The crystal structure of a voltage-gated sodium channel. Nature 2011;475(7356):353-358.

[99] Perez-Reyes E. Molecular physiology of low-voltage-activated t-type calcium channels. Physiol Rev 2003;83(1):117-161.

[100] Perez-Reyes E, Cribbs LL, Daud A, Lacerda AE, Barclay J, Williamson MP, Fox M, Rees M, Lee JH. Molecular characterization of a neuronal low-voltage-activated T-type calcium channel. Nature 1998;391(6670):896-900

[101] Pinchenko VO, Kostyuk PG, Kostyuk EP. Influence of external pH on two types of low-voltageactivated calcium currents in primary sensory neurons of rats. Biochim Biophys Acta 2005;1724(1-2):1-7.

[102] Powell KL, Cain SM, Ng C, Sirdesai S, David LS, Kyi M, Garcia E, Tyson JR, Reid CA, Bahlo M, Foote SJ, Snutch TP, O'Brien TJ. A Cav3.2 T-type calcium channel point mutation has splice-variant-specific effects on function and segregates with seizure expression in a polygenic rat model of absence epilepsy. J Neurosci 2009;29(2):371-380.

[103] Reynders A, Mantilleri A, Malapert P, Rialle S, Nidelet S, Laffray S, Beurrier C, Bourinet E, Moqrich A. Transcriptional Profiling of Cutaneous MRGPRD Free Nerve Endings and CLTMRs. Cell Rep 2015;10(6):1007-1019.

[104] Rhim H, Lee YS, Park SJ, Chung BY, Lee JY. Synthesis and biological activity of 3,4dihydroquinazolines for selective T-type $\mathrm{Ca}(2+)$ channel blockers. Bioorg Med Chem Lett 2005;15(2):283-286. 
[105] Saab CY. Pain-related changes in the brain: diagnostic and therapeutic potentials. Trends Neurosci 2012;35(10):629-637.

[106] Samour MS, Nagi SS, Mahns DA. Cav3.2-expressing low-threshold C fibres in human hairy skin contribute to cold allodynia-a non-TRPV1- and non-TRPM8-dependent phenomenon. Pain 2015;156(8):1566-1575.

[107] Sarnthein J, Stern J, Aufenberg C, Rousson V, Jeanmonod D. Increased EEG power and slowed dominant frequency in patients with neurogenic pain. Brain 2006;129(Pt 1):55-64.

[108] Scholl UI, Stölting G, Nelson-Williams C, Vichot AA, Choi M, Loring E, Prasad ML, Goh G, Carling T, Juhlin CC, Quack I, Rump LC, Thiel A, Lande M, Frazier BG, Rasoulpour M, Bowlin DL, Sethna CB, Trachtman H, Fahlke C, Lifton RP. Recurrent gain of function mutation in calcium channel CACNA1H causes early-onset hypertension with primary aldosteronism, Vol. 4, 2015.

[109] Scroggs RS, Fox AP. Calcium current variation between acutely isolated adult rat dorsal root ganglion neurons of different size. J Physiol 1992;445:639-658.

[110] Senatore A, Spafford JD. Gene transcription and splicing of T-type channels are evolutionarilyconserved strategies for regulating channel expression and gating. PloS one 2012;7(6):e37409.

[111] Serra J, Duan WR, Locke C, Sola R, Liu W, Nothaft W. Effects of a T-type calcium channel blocker, ABT-639, on spontaneous activity in C-nociceptors in patients with painful diabetic neuropathy: a randomized controlled trial. Pain 2015.

[112] Shelton L, Becerra L, Borsook D. Unmasking the mysteries of the habenula in pain and analgesia. Progress in neurobiology 2012;96(2):208-219.

[113] Shen FY, Chen ZY, Zhong W, Ma LQ, Chen C, Yang ZJ, Xie WL, Wang YW. Alleviation of neuropathic pain by regulating T-type calcium channels in rat anterior cingulate cortex. Mol Pain 2015;11(1):7.

[114] Shen Y, Yu D, Hiel H, Liao P, Yue DT, Fuchs PA, Soong TW. Alternative splicing of the Ca(v)1.3 channel IQ domain, a molecular switch for Ca2+-dependent inactivation within auditory hair cells. J Neurosci 2006;26(42):10690-10699. 
[115] Shin JB, Martinez-Salgado C, Heppenstall PA, Lewin GR. A T-type calcium channel required for normal function of a mammalian mechanoreceptor. Nat Neurosci 2003;6(7):724-730.

[116] Shipe WD, Barrow JC, Yang ZQ, Lindsley CW, Yang FV, Schlegel KA, Shu Y, Rittle KE, Bock MG, Hartman GD, Tang C, Ballard JE, Kuo Y, Adarayan ED, Prueksaritanont T, Zrada MM, Uebele VN, Nuss CE, Connolly TM, Doran SM, Fox SV, Kraus RL, Marino MJ, Graufelds VK, Vargas HM, Bunting PB, Hasbun-Manning M, Evans RM, Koblan KS, Renger JJ. Design, synthesis, and evaluation of a novel 4-aminomethyl-4-fluoropiperidine as a T-type Ca2+ channel antagonist. J Med Chem 2008;51(13):3692-3695.

[117] Shyu BC, Vogt BA. Short-term synaptic plasticity in the nociceptive thalamic-anterior cingulate pathway. Mol Pain 2009;5:51.

[118] Splawski I, Yoo DS, Stotz SC, Cherry A, Clapham DE, Keating MT. CACNA1H mutations in autism spectrum disorders. J Biol Chem 2006;281(31):22085-22091.

[119] Steriade M, McCormick DA, Sejnowski TJ. Thalamocortical oscillations in the sleeping and aroused brain. Science 1993;262(5134):679-685.

[120] Takahashi T, Aoki Y, Okubo K, Maeda Y, Sekiguchi F, Mitani K, Nishikawa H, Kawabata A. Upregulation of $\mathrm{Ca}(\mathrm{v}) 3.2$ T-type calcium channels targeted by endogenous hydrogen sulfide contributes to maintenance of neuropathic pain. Pain 2010;150(1):183-191.

[121] Talley EM, Cribbs LL, Lee JH, Daud A, Perez-Reyes E, Bayliss DA. Differential distribution of three members of a gene family encoding low voltage-activated (T-type) calcium channels. J Neurosci 1999;19(6):1895-1911.

[122] Tan GM, Yu D, Wang J, Soong TW. Alternative splicing at C terminus of $\mathrm{Ca}(\mathrm{V}) 1.4$ calcium channel modulates calcium-dependent inactivation, activation potential, and current density. $\mathrm{J}$ Biol Chem 2012;287(2):832-847.

[123] Tang ZZ, Liang MC, Lu S, Yu D, Yu CY, Yue DT, Soong TW. Transcript scanning reveals novel and extensive splice variations in human l-type voltage-gated calcium channel, Cav1.2 alpha1 subunit. J Biol Chem 2004;279(43):44335-44343. 
[124] Terada Y, Fujimura M, Nishimura S, Tsubota M, Sekiguchi F, Kawabata A. Roles of Cav3.2 and TRPA1 channels targeted by hydrogen sulfide in pancreatic nociceptive processing in mice with or without acute pancreatitis. Journal of neuroscience research 2015;93(2):361-369.

[125] Todorovic SM, Jevtovic-Todorovic V. The role of T-type calcium channels in peripheral and central pain processing. CNS Neurol Disord Drug Targets 2006;5(6):639-653.

[126] Todorovic SM, Jevtovic-Todorovic V. Neuropathic pain: role for presynaptic T-type channels in nociceptive signaling. Pflugers Arch 2013;465(7):921-927.

[127] Todorovic SM, Jevtovic-Todorovic V, Meyenburg A, Mennerick S, Perez-Reyes E, Romano C, Olney JW, Zorumski CF. Redox modulation of T-type calcium channels in rat peripheral nociceptors. Neuron 2001;31(1):75-85.

[128] Tscherter A, David F, Ivanova T, Deleuze C, Renger JJ, Uebele VN, Shin HS, Bal T, Leresche N, Lambert RC. Minimal alterations in T-type calcium channel gating markedly modify physiological firing dynamics. J Physiol 2011;589(Pt 7):1707-1724.

[129] Turner RW, Zamponi GW. T-type channels buddy up. Pflugers Arch 2014.

[130] Uebele VN, Nuss CE, Fox SV, Garson SL, Cristescu R, Doran SM, Kraus RL, Santarelli VP, Li Y, Barrow JC, Yang ZQ, Schlegel KA, Rittle KE, Reger TS, Bednar RA, Lemaire W, Mullen FA, Ballard JE, Tang C, Dai G, McManus OB, Koblan KS, Renger JJ. Positive allosteric interaction of structurally diverse T-type calcium channel antagonists. Cell Biochem Biophys 2009;55(2):81-93.

[131] Usoskin D, Furlan A, Islam S, Abdo H, Lonnerberg P, Lou D, Hjerling-Leffler J, Haeggstrom J, Kharchenko O, Kharchenko PV, Linnarsson S, Ernfors P. Unbiased classification of sensory neuron types by large-scale single-cell RNA sequencing. Nat Neurosci 2015;18(1):145-153.

[132] van Loo KM, Schaub C, Pernhorst K, Yaari Y, Beck H, Schoch S, Becker AJ. Transcriptional regulation of T-type calcium channel CaV3.2: bi-directionality by early growth response 1 (Egr1) and repressor element 1 (RE-1) protein-silencing transcription factor (REST). J Biol Chem 2012;287(19):15489-15501. 
[133] Vitko I, Bidaud I, Arias JM, Mezghrani A, Lory P, Perez-Reyes E. The I-II loop controls plasma membrane expression and gating of $\mathrm{Ca}(\mathrm{v}) 3.2 \mathrm{~T}$-type Ca2+ channels: a paradigm for childhood absence epilepsy mutations. J Neurosci 2007;27(2):322-330.

[134] Walsh MA, Graham BA, Brichta AM, Callister RJ. Evidence for a critical period in the development of excitability and potassium currents in mouse lumbar superficial dorsal horn neurons. J Neurophysiol 2009;101(4):1800-1812.

[135] Walton KD, Llinas RR. Central Pain as a Thalamocortical Dysrhythmia: A Thalamic Efference Disconnection? In: L Kruger, AR Light, editors. Translational Pain Research: From Mouse to Man. Boca Raton, FL, 2010.

[136] Wang R, Lewin GR. The Cav3.2 T-type calcium channel regulates temporal coding in mouse mechanoreceptors. J Physiol 2011;589(Pt 9):2229-2243.

[137] Weiss N, Black SA, Bladen C, Chen L, Zamponi GW. Surface expression and function of Ca3.2 T-type calcium channels are controlled by asparagine-linked glycosylation. Pflugers Arch 2013.

[138] Weiss N, Hameed S, Fernandez-Fernandez JM, Fablet K, Karmazinova M, Poillot C, Proft J, Chen L, Bidaud I, Monteil A, Huc-Brandt S, Lacinova L, Lory P, Zamponi GW, De Waard M. A Ca(v)3.2/syntaxin-1A signaling complex controls T-type channel activity and low-threshold exocytosis. J Biol Chem 2012;287(4):2810-2818.

[139] Weiss N, Zamponi GW. Control of low-threshold exocytosis by T-type calcium channels. Biochim Biophys Acta 2012.

[140] Wen XJ, Xu SY, Chen ZX, Yang CX, Liang H, Li H. The roles of T-type calcium channel in the development of neuropathic pain following chronic compression of rat dorsal root ganglia. Pharmacology 2010;85(5):295-300.

[141] Wheeler DG, Groth RD, Ma H, Barrett CF, Owen SF, Safa P, Tsien RW. Ca(V)1 and Ca(V)2 channels engage distinct modes of $\mathrm{Ca}(2+)$ signaling to control CREB-dependent gene expression. Cell 2012;149(5):1112-1124.

[142] Woo CW, Roy M, Buhle JT, Wager TD. Distinct brain systems mediate the effects of nociceptive input and self-regulation on pain. PLoS biology 2015;13(1):e1002036. 
[143] Yang ZQ, Barrow JC, Shipe WD, Schlegel KA, Shu Y, Yang FV, Lindsley CW, Rittle KE, Bock MG, Hartman GD, Uebele VN, Nuss CE, Fox SV, Kraus RL, Doran SM, Connolly TM, Tang C, Ballard JE, Kuo Y, Adarayan ED, Prueksaritanont T, Zrada MM, Marino MJ, Graufelds VK, DiLella AG, Reynolds IJ, Vargas HM, Bunting PB, Woltmann RF, Magee MM, Koblan KS, Renger JJ. Discovery of 1,4-substituted piperidines as potent and selective inhibitors of T-type calcium channels. J Med Chem 2008;51(20):6471-6477.

[144] Yue J, Liu L, Liu Z, Shu B, Zhang Y. Upregulation of T-type Ca2+ Channels in Primary Sensory Neurons in Spinal Nerve Injury. Spine 2013;38(6):463-470.

[145] Zamponi GW, Lory P, Perez-Reyes E. Role of voltage-gated calcium channels in epilepsy. Pflugers Arch;460(2):395-403.

[146] Zhang Q, Xia Z, Joshi S, Scott VE, Jarvis MF. Optimization of ADME Properties for Sulfonamides Leading to the Discovery of a T-Type Calcium Channel Blocker, ABT-639. ACS medicinal chemistry letters 2015;6(6):641-644.

[147] Ziegler D, Duan WR, An G, Thomas JW, Nothaft W. A randomized double-blind, placebo- and active-controlled study of T-type calcium channel blocker ABT-639 in diabetic patients with peripheral neuropathic pain. Pain 2015. 